\title{
Mitochondrial DNA polymorphism and heteroplasmy in populations of the three species of Tropidurus of the nanuzae group (Squamata, Tropiduridae)
}

\author{
José Carlos Passoni ${ }^{1}$, Maria Lúcia Benozzatil ${ }^{1}$ and Miguel Tréfaut Rodrigues ${ }^{2,3}$
}

\begin{abstract}
The nanuzae group of lizards includes three species, Tropidurus nanuzae, T. divaricatus and T. amathites. The first species is found along Serra do Espinhaço, in eastern Brazil, and the other two in the northern region of the Brazilian State of Bahia, in continental dunes on both margins of the São Francisco River. Restriction fragment length polymorphisms (RFLP) of the mtDNA in these species were detected in 53 restriction sites. Site and fragment length polymorphisms were characterized, and cases of heteroplasmy involving length variation were observed. In T. divaricatus, these variations involved changes of 50-200 bp, probably in the control region of the molecule. In T. amathites, variation was apparently due to duplication/deletion of a 400-bp segment. Fragment length mutation rate varied among the species, being smaller in T. amathites than in T. divaricatus. Relatively low nucleotide diversity values were detected in these populations, the smallest being found in T. nanuzae. The most polymorphic population was T. divaricatus from Alagoado, followed by that of the same species from Ibiraba, suggesting both probable recovery of mtDNA genetic diversity after putative reductions in population size, and recent population expansion.
\end{abstract}

\section{INTRODUCTION}

The Tropidurus nanuzae species group is a monophyletic assemblage of tropidurid lizards, as proposed by Rodrigues in 1986. It comprises three species: Tropidurus nanuzae, T. divaricatus and T. amathites. T. nanuzae is found along the Serra do Espinhaço mountain range, in the Brazilian States of Minas Gerais and Bahia, at altitudes around or above $900 \mathrm{~m}$. The other two species live in the northern part of Bahia State, in São Francisco River dunes: T. amathites is found in Santo Inácio and Lagoa de Itaparica on the river's eastern bank, and T. divaricatus, in Queimadas, Ibiraba, Manga and Alagoado, in two separate sand dune fields on the west margin. T. divaricatus from Queimadas and Ibiraba can be considered a single population, since they are spatially continuous (Rodrigues, 1986). There have been morphological (Rodrigues, 1986; Skuk, 1994), allozymic (Martins, 1991, 1995) and chromosomal (Kasahara et al., 1987) studies of the nanuzae group. Although T. nanuzae is predominantly saxicolous, one population (Pedra Menina) lives in sand. The other two species are psamophilic. According to Rodrigues (1986, 1996), nanuzae is the sister species of the pair amathites/ divaricatus, which are closely related and geographically isolated by the river.

The mtDNA RFLP (restriction fragment length polymorphisms) analysis method has been applied to population studies, allowing detection of mtDNA size variations (e.g., Moritz and Brown, 1986, 1987; Moritz et al., 1993). Such data can be related to genetic diversity and size poly- morphisms of the molecule. Size differences in mtDNA are common among closely related species, ranging from a few base pairs to $8 \mathrm{~kb}$ (Moritz and Brown, 1987; Moritz et al., 1987). These differences can be due to i) variation in the number of nucleotides in homopolymer tracts, ii) variation in copy number of tandem repeats, and iii) duplications or deletions of large sequences (Moritz et al., 1987). In size polymorphisms, the presence of two or more types of mtDNA molecules in the same individual (heteroplasmy) is relatively common.

The genetic structure of populations of three species of lizards of the Tropidurus nanuzae group was studied using restriction fragment analyses of mtDNA.

\section{MATERIAL AND METHODS}

Samples from six populations of the three species of the nanuzae group of lizards were analyzed (Figure 1; Table I). Heart, liver and portions of skeletal muscle were stored at $-196^{\circ} \mathrm{C}$. DNA, enriched in the mitochondrial fraction, was obtained according to Hillis and Davis (1986) and Dowling et al. (1990), modified. Approximately $0.5 \mathrm{~g}$ of these tissues was taken from each specimen, and pulverized to fine powder in liquid nitrogen, using a prechilled mortar and pestle. The powder was suspended in STES (0.01 M NaCl, 0.01 M Tris, 0.1 M EDTA, $0.25 \mathrm{M}$ sucrose, $\mathrm{pH}=7.5)$, in a buffer:tissue ratio of approximately $12 \mathrm{ml}: 1 \mathrm{~g}$, and then centrifuged for $5 \mathrm{~min}$, at $1,200 \mathrm{~g}$, to pellet nuclei. The supernatant was centrifuged at $23,000 \mathrm{~g}$ for $20 \mathrm{~min}$ at $4^{\circ} \mathrm{C}$, for mitochondria precipitation. The

Departamentos de ${ }^{1}$ Biologia and ${ }^{2}$ Zoologia, Instituto de Biociências, Universidade de São Paulo, Rua do Matão, 277, Cidade Universitária, 05508-900 São Paulo, SP, Brasil. Send correspondence to J.C.P. E-mail: cpassoni@ib.usp.br

${ }^{3}$ Museu de Zoologia, Universidade de São Paulo, São Paulo, SP, Brasil 
pellet was suspended in STE $(0.1 \mathrm{M} \mathrm{NaCl}, 0.01 \mathrm{M}$ Tris, $0.1 \mathrm{M}$ EDTA, $\mathrm{pH}=7.5$ ), with $1 \%$ sodium dodecyl sulfate (SDS) and $10 \mathrm{U} / \mathrm{ml}$ of proteinase $\mathrm{K}$. After incubation for $2 \mathrm{~h}$ at $55^{\circ} \mathrm{C}$, the preparation was extracted with one volume of phenol, and then with one volume of 24:1 chloroform:isoamyl alcohol solution. DNA was precipitated from the supernatant by the addition of $1 / 10$ volume of a $3 \mathrm{M} \mathrm{NaCl}$, $0.25 \mathrm{M}$ Tris, and 0.1 M EDTA solution and 2.5 volumes of $95 \%$ ethanol at $-20^{\circ} \mathrm{C}$ overnight. The DNA pelleted after 10 min centrifuging at $23,000 \mathrm{~g}$ at $4^{\circ} \mathrm{C}$ was dissolved in $100 \mu \mathrm{l}$ of TE ( $0.01 \mathrm{M}$ Tris, $0.001 \mathrm{M}$ EDTA, $\mathrm{pH}=8.0)$, and reextracted with phenol and chloroform:isoamyl alcohol. The DNA was then precipitated by one volume of a PEG solution, for $2 \mathrm{~h}$ at $5^{\circ} \mathrm{C}$, and finally centrifuged for $10 \mathrm{~min}$ at 23,000 $\mathrm{g}$. The pellet was washed in $80 \%$ ethanol, air dried

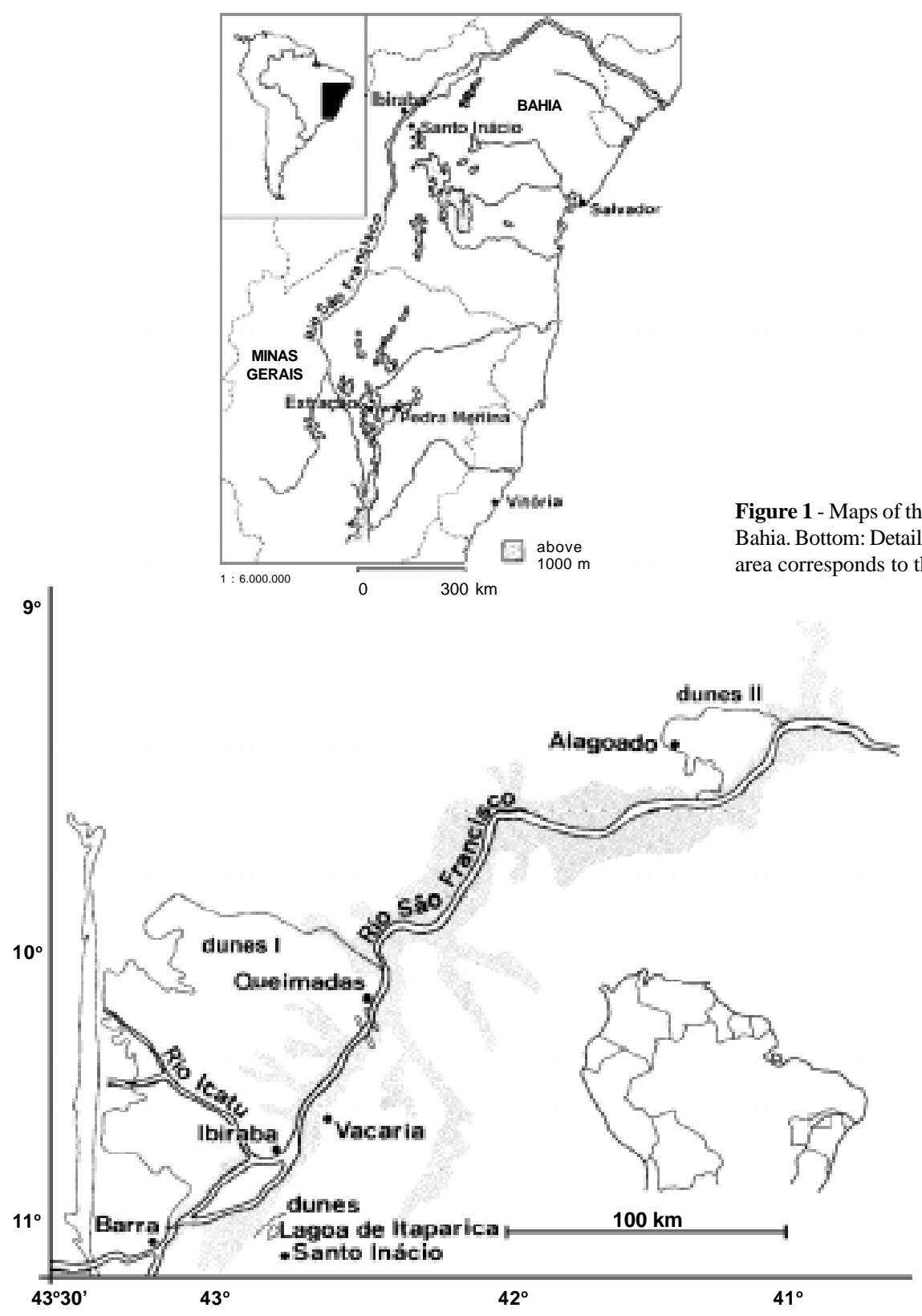

and dissolved in 40-60 $\mu \mathrm{l}$ of TE. This last purification step proved to be necessary for proper activity of the endonucleases. The liquid nitrogen-powdered tissues from each specimen yielded approximately 3 to $4 \mu \mathrm{g}$ of DNA, enriched in the mitochondrial fraction.

From 10 to $20 \mathrm{U}$ of the restriction endonucleases were used to digest $0.3-0.4 \mu \mathrm{g}$ of DNA in $30 \mu \mathrm{l}$ reactions, following manufacturer specifications (New England Biolabs). Enzymes effectively used in the analyses were BclI, DraI, EcoRI, EcoRV, HindIII, PstI, PvuII and XhoI. Eleven additional endonucleases were used in initial screening, but discarded because they produced too many cuts in the mtDNA, generating uninformative restriction fragment patterns. Double digestions with endonucleases $P v u \mathrm{II}$ and $\mathrm{XhoI}$ and with EcoRI and PstI were also performed in order to map Bahia. Bottom: Detail of the northern region of the State of Bahia (the stippled Sobradinho hydroelectric dam reservoir). 
some unidentified sites. After digestion, the DNA was electrophoresed on $0.8 \%$ agarose gels containing ethidium bromide at a final concentration of $0.4 \mu \mathrm{g} / \mathrm{ml}(50 \mathrm{~V}, 4-6 \mathrm{~h})$, and photographed. HindIII $\lambda$ DNA digests and pBR 328 digested with BamHI, BglI and HinfI were used as molecular size standards: the fragment sizes in base pairs (bp) were 23,130; 9,$416 ; 6,557 ; 4,907 ; 4,361 ; 2,322 ; 2,176 ; 2,023 ; 1,766$ and 1,230 . Restriction fragments were transferred from the gel to a nylon membrane ("Nylon Membrane Positive Charged"Boehringer Mannheim). A heterologous probe of mtDNA obtained from human placenta (Hauswirth et al., 1987) was labeled with digoxigenin ("DIG DNA labeling and detection kit"-Boehringer Mannheim), and hybridization and DNA detection performed according to manufacturer protocols. The nylon membranes were photographed with T-MAX 100 film (KODAK), just after band detection. Nucleotide (p) and haplotype (h) diversity indices were calculated for each population according to Nei and Li (1979) and Nei and Tajima (1981), respectively.

\section{RESULTS}

The T. nanuzae population from Extração had a restriction site polymorphism with one enzyme while the conspecific population from Pedra Menina was monomorphic for all enzymes used. There was site variation in three of the eight endonucleases in T. amathites. The T. divaricatus sample from Alagoado had restriction site polymorphisms with three endonucleases. The Ibiraba population was polymorphic with six endonucleases, while the Queimadas sample was monomorphic for all enzymes; restriction fragment patterns in this population corresponded to the most frequent ones observed in the Ibiraba sample. The apparent size variation in the heaviest fragment among HindIII patterns of T. divaricatus from Alagoado (Figure 2) probably corresponds to a site variation, because the apparent size difference would correspond to about $1 \mathrm{~kb}$, a difference significantly greater than the size variation detected by the other enzymes.

Fourteen haplotypes were characterized in the nanuzae group (Table II). A presence versus absence restriction site matrix was used to calculate nucleotide diversities (p) and haplotype diversities (h) for each population analyzed (Table III). The "p" values ranged from 0 to $0.37 \%$. The nucleotide diversity of the $T$. divaricatus sample from Alagoado was greater than that observed in the population of the same river margin, in Queimadas/ Ibiraba. The most polymorphic sample was $T$. divaricatus from Alagoado, followed by $T$. amathites and $T$. divaricatus from Queimadas/Ibiraba. The T. nanuzae population from Extração had a low degree of polymorphism, while the Pedra Menina sample was monomorphic.

Besides site polymorphisms, mtDNA size variation was also detected in some populations. In T. amathites, it corresponded to approximately $400 \mathrm{bp}$ in fragments generated by five enzymes. In T. divaricatus from Alagoado,
Table I - Sample sizes of the populations from the three species of the Tropidurus nanuzae group.

\begin{tabular}{|lcc|}
\hline Species & Location & Sample size \\
\hline T. divaricatus & Ibiraba & 7 \\
& Queimadas & 4 \\
T. amathites & Alagoado & 7 \\
T. nanuzae & Santo Inácio & 16 \\
& Extração & 4 \\
& Pedra Menina & 5 \\
\hline
\end{tabular}

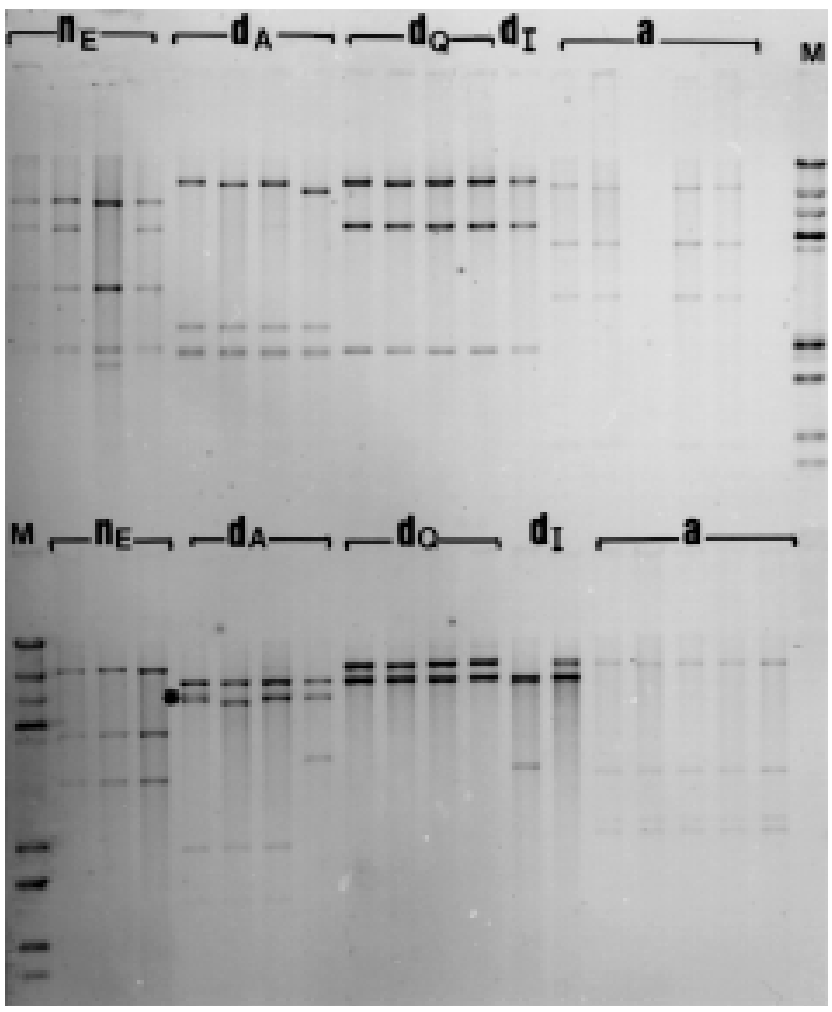

Figure 2 - mtDNA fragment patterns of Tropidurus nanuzae from Extração $\left(\mathrm{n}_{\mathrm{E}}\right)$, T. divaricatus from Alagoado $\left(\mathrm{d}_{\mathrm{A}}\right)$, Queimadas $\left(\mathrm{d}_{\mathrm{O}}\right)$ and Ibiraba $\left(\mathrm{d}_{\mathrm{H}}\right)$ and T. amathites (a) using the enzymes HindIII (top) and BclI (bottom). $\lambda$ DNA (HindIII) and pBR 328 (BamHI, BglI and HinfI) were used as molecular size standards (M). (*) Molecular size variation and heteroplasmy.

size variations with three endonucleases were detected. They were also found in the population from Queimadas/ Ibiraba, with four endonucleases. Differently from $T$. amathites, variations detected in $T$. divaricatus show a continuous pattern, with minimal size differences of approximately 50 to $100 \mathrm{bp}$ (see Figures 2 and 3).

Frequency distributions of mtDNA size classes were constructed, considering bands of different intensities in digestion profiles as having approximately the same stoichiometric fragment contents (Figure 4). There were two discrete size classes for $T$. amathites, differing in about 400 bp. In T. divaricatus from Queimadas/Ibiraba, molecules differing in $200 \mathrm{bp}$ were detected, whereas in that 
Table II - Haplotypes of the Tropidurus nanuzae group populations analyzed. Capital letters refer to the digestion profiles of BclI, DraI, EcoRI, EcoRV, HindIII, PstI, PvuII and XhoI, from left to right. The haplotypes are designated by the name of the species, followed by the locality abbreviations ( $\mathrm{Ex}=$ Extração; $\mathrm{PM}=$ Pedra Menina; $\mathrm{Q}=$ Queimadas; $\mathrm{Ib}=$ Ibiraba; $\mathrm{Al}=$ Alagoado). Haplotypes are numbered according to frequencies.

\begin{tabular}{|cccccccccc|}
\hline & \multicolumn{1}{c}{ Haplotypes } & & & Designations & $\begin{array}{c}\text { Numbers of } \\
\text { individuals }\end{array}$ \\
\hline F & D & E & C & G & D & F & C & nanuzaeEx1 & 3 \\
F & D & E & C & J & D & F & C & nanuzaeEx2 & 1 \\
G & H & F & C & H & A & G & F & nanuzaePM1 & 3 \\
A & A & A & A & A & A & A & A & divaricatusQ/Ib1 & 8 \\
A & H & A & A & A & A & A & A & divaricatusIb2 & 1 \\
B & A & B & A & B & A & B & A & divaricatusIb3 & 1 \\
D & B & C & B & C & B & C & B & divaricatusA11 & 3 \\
D & B & C & C & C & B & C & B & divaricatusA12 & 1 \\
D & B & C & B & D & B & C & B & divaricatusA13 & 1 \\
C & B & C & B & D & B & C & B & divaricatusA14 & 1 \\
C & B & C & B & E & B & C & B & divaricatusA15 & 1 \\
E & C & D & C & F & C & D & C & amathites1 & 6 \\
E & C & D & D & F & C & E & D & amathites2 & 2 \\
E & C & D & C & F & C & D & E & amathites3 & 1 \\
\hline
\end{tabular}

Table III - Nucleotide diversity (p) and haplotype diversity (h) estimated for the Tropidurus populations sampled.

\begin{tabular}{|lll|}
\hline Population & $\mathrm{p}$ & $\mathrm{h}$ \\
\hline T. divaricatus (Queimadas/Ibiraba) & $0.19 \%$ & 0.45 \\
T. divaricatus (Alagoado) & $0.25 \%$ & 0.73 \\
T. amathites (Santo Inácio) & $0.37 \%$ & 0.49 \\
T. nanuzae (Extração) & $0.08 \%$ & 0.38 \\
T. nanuzae (Pedra Menina) & $0 \%$ & 0 \\
\hline
\end{tabular}

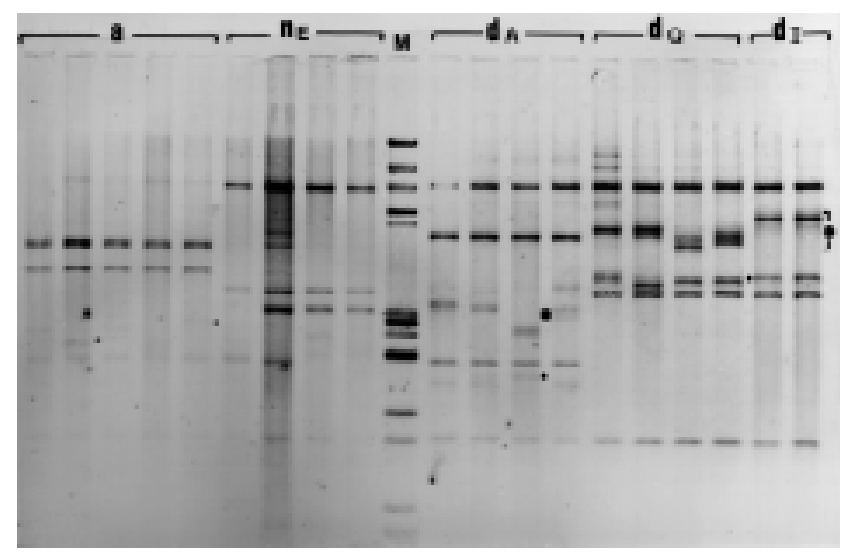

Figure 3 - mtDNA fragment patterns of Tropidurus amathites (a), T. nanuzae from Extração $\left(\mathrm{n}_{\mathrm{E}}\right)$, T. divaricatus from Alagoado $\left(\mathrm{d}_{\mathrm{A}}\right)$, Queimadas $\left(\mathrm{d}_{\mathrm{Q}}\right)$, and Ibiraba ( $\mathrm{d}_{\mathrm{I}}$ ) of DraI. $\lambda$ DNA (HindIII) and pBR 328 (BamHI, BglI and HinfI) were used as molecular size standards (M). (*) Molecular size variation and heteroplasmy. of Alagoado minimal size differences ranged approximately from 50 to $100 \mathrm{bp}$. Smallest and longest molecules and mean sizes of the mtDNA with standard deviations were estimated for each population (Table IV). No length polymorphism was found for T. nanuzae, and mtDNA molecules of this species were approximately $1 \mathrm{~kb}$ smaller than the molecules of the other two species. The most significant size variations were detected in the populations of $T$. divaricatus. Heteroplasmic individuals with two or more size classes of mtDNA were also detected in this species.

In the Queimadas/Ibiraba sample, four enzymes revealed heteroplasmic individuals, at a $91 \%$ frequency, and in the conspecific sample from Alagoado, the enzyme DraI revealed $100 \%$ heteroplasmy (see Figure 3). No heteroplasmic individuals were found in T. amathites and $T$. nanuzae.

\section{DISCUSSION}

\section{Genetic diversity values}

The Alagoado population of T. divaricatus had a relatively low nucleotide diversity $(\mathrm{p}=0.25 \%)$, considering that "p" ranges from 0.05 to $2 \%$ (Stephan and Langley, 1992). However, the haplotype diversity for this population $(\mathrm{h}=0.73)$ was the highest among the six populations, comparable to those found for rapidly evolving genomes ("h" ranges from 0.0 to near 1.0; Avise, 1994). Martins (1991, 1995), in an allozymic study of the nanuzae group, obtained a mean heterozigosity $(\mathrm{H})$ of 0.065 and a proportion of polymorphic loci $(\% \mathrm{P})$ of $22.2 \%$, proposing a recent bottleneck to account for these reduced values. The " $p$ " value from mtDNA data is compatible with Martins's indices, but the " $h$ " value is not.

The Queimadas/Ibiraba population of T. divaricatus had lower mtDNA genetic diversity values $(\mathrm{p}=0.19 \%$ and $\mathrm{h}=0.45$ ) than the Alagoado indices. However, the allozymic data (Martins, 1991, 1995) had relatively high values for the Ibiraba population $(\mathrm{H}=0.103$ and $\mathrm{P}=$ $44.4 \%$ ). If mtDNA diversity indices are calculated only for Ibiraba, the " $h$ " value increases to 0.61 , while the " $p$ " value goes up to $0.31 \%$, approximating the allozymic data.

The "p" value $(0.37 \%)$ for T. amathites was the highest found in the nanuzae group, while the mtDNA haplotype diversity $(h=0.49)$ was consistently lower than that obtained for T. divaricatus from Alagoado. The allozyme data (Martins, 1991, 1995) are compatible with the mtDNA data: the mean heterozigosity $(\mathrm{H}=0.077)$ and the proportion of polymorphic loci $(\% \mathrm{P}=33.3 \%)$ are also low (see Avise, 1994).

Similar mtDNA restriction site data were obtained for the microteiid lizards of genus Calyptommatus (Squamata, Gymnophtalmidae), which are also restricted to the same sand dunes on opposite banks of the São Francisco River (Arruda Campos, 1999): significant haplotype diversity was found only in the population from Alagoado (C. leiolepis), among the three species of this genus. 

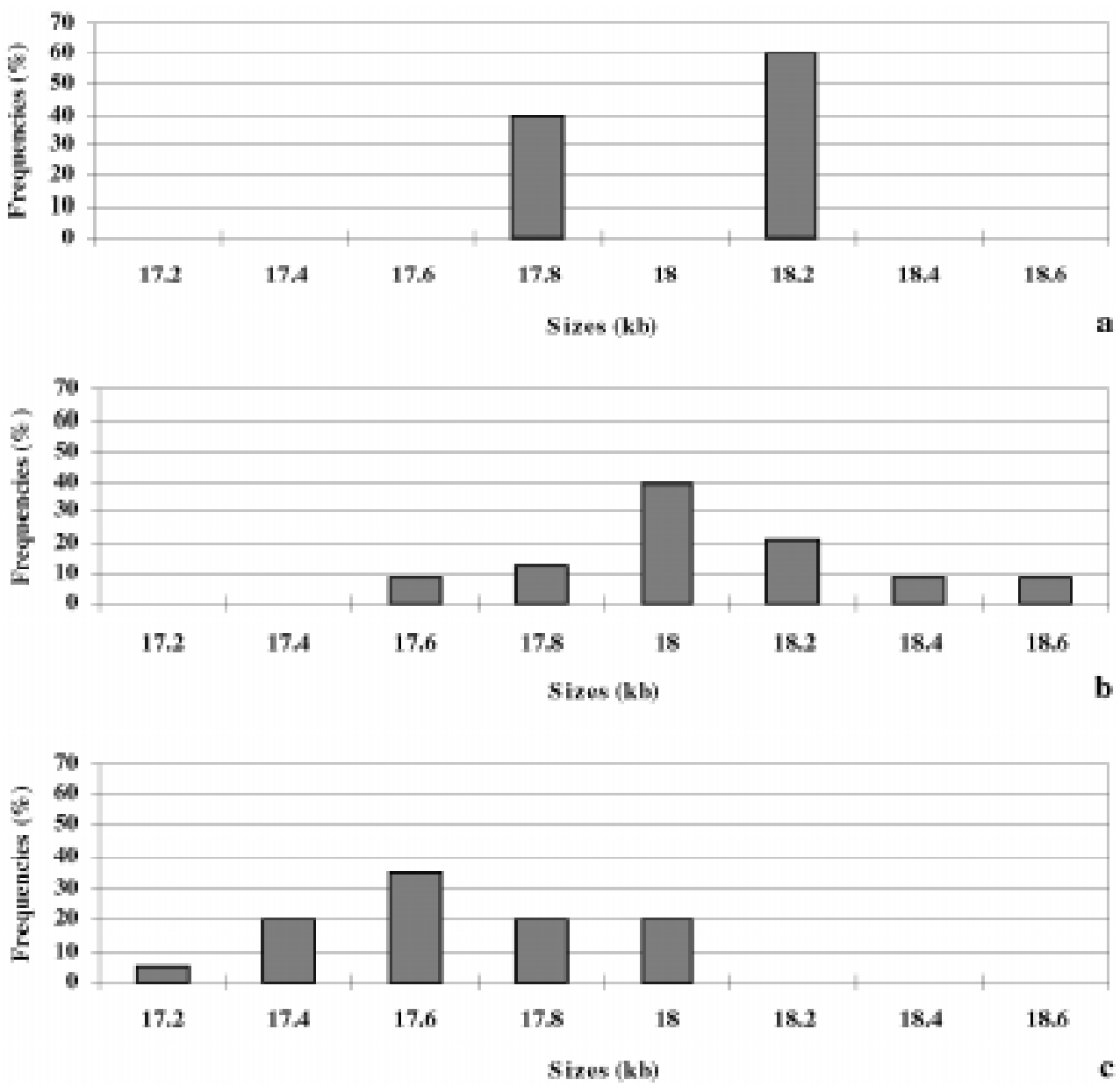

Figure 4 - Frequency distributions of mtDNA size classes in Tropidurus amathites (a) and T. divaricatus from Queimadas/Ibiraba (b) and Alagoado (c).

Both populations of T. nanuzae (Extração and Pedra Menina) had low genetic diversity, as also found with allozymic analysis (Martins, 1991, 1995). More severe habitat restrictions in the recent past were proposed by Martins for these populations, since this species is not continuously distributed along the Serra do Espinhaço mountain range.

Table IV - Approximate sizes (kb) of the mtDNA molecules in the Tropidurus populations analyzed

\begin{tabular}{|c|c|c|c|c|}
\hline Species & Location & $\begin{array}{l}\text { Shortest } \\
\text { molecule }\end{array}$ & $\begin{array}{l}\text { Longest } \\
\text { molecule }\end{array}$ & $\begin{array}{c}\text { Mean size } \\
\pm \text { standard } \\
\text { deviation }\end{array}$ \\
\hline T. divaricatus & $\begin{array}{c}\text { Queimadas/ } \\
\text { Ibiraba }\end{array}$ & 17.6 & 18.6 & $18.1 \pm 0.3$ \\
\hline T. divaricatus & Alagoado & 17.2 & 18.0 & $17.7 \pm 0.2$ \\
\hline T. amathites & Santo Inácio & 17.8 & 18.2 & $18.0 \pm 0.2$ \\
\hline T. nanuzae & Extração & - & - & $17.2 \pm 0.2$ \\
\hline T. nanuzae & Pedra Menina & - & - & $17.2 \pm 0.2$ \\
\hline
\end{tabular}

Size polymorphisms and heteroplasmy

Mitochondrial DNA size polymorphisms were found in T. divaricatus and T. amathites. Frequency distributions of different mtDNA size classes in T. divaricatus (Figure $4 \mathrm{~b}$ and c) were similar to those found for variable number of repeats in the control region in other vertebrate species as codfishes and bats (Rand, 1993). These distributions are characterized by a modal size class, and are skewed with longer tail toward larger genomes. The mechanism generating size differences in T. divaricatus may also be variation in the number of small repeats in the mtDNA control region. However, in T. amathites, size variation seems to be related to a unique sequence duplication or deletion of about $400 \mathrm{bp}$ (Figure 4a). In lizards, size variations of mtDNA are frequent. For instance, in sexual and parthenogenetic lizards of the genus Cnemidophorus, Densmore et al. (1985) observed length variations, ranging from tens to hundreds of base pairs, that were attributed to changes in the number of 64-bp repeats and to small additions and deletions in the control region. In the 
nanuzae group, the magnitude of mtDNA size variations was different in each of the three populations: significant differences between the largest and the smallest molecules were detected, particularly in $T$. divaricatus from Queimadas/Ibiraba (see Table IV). This high degree of variation is compatible with the low metabolic rates of ectotherms (Rand, 1993): at lower metabolic rates a weak pressure would exist against longer genomes, yielding significant amounts of large molecules along with smaller molecules.

High levels of heteroplasmy involving size variants of the mtDNA molecule were detected in T. divaricatus samples from Queimadas/Ibiraba and Alagoado. This kind of heteroplasmy has often been described in other taxa. In the lizard species Cnemidophorus tesselatus and C. tigris, Densmore et al. (1985) detected 25 and 20\% of heteroplasmic individuals, respectively. Árnason and Rand (1992) observed 100\% heteroplasmy in the Atlantic cod (Gadus morhua), with two or more mtDNA size variants in each individual. Therefore, the 91 and $100 \%$ frequencies in those $T$. divaricatus populations are compatible with previously reported indices.

\section{ACKNOWLEDGMENTS}

We thank Lurdes F. de Almeida-Toledo and J. Rodolfo Lima for critical reading the manuscript and José Manoel Martins for collecting the tissue samples in the field. We are also grateful to Francisco G. Nóbrega for assistance in obtaining the probe. This work was supported by CNPq, FAPESP and FINEP. Publication supported by FAPESP.

\section{RESUMO}

O grupo nanuzae de lagartos compreende três espécies, Tropidurus nanuzae, T. divaricatus e T. amathites. A primeira é encontrada ao longo da Serra do Espinhaço, na região leste do Brasil, e as outras duas na região norte do Estado da Bahia, nas dunas continentais do Rio São Francisco, em margens opostas. Essas três espécies foram analisadas quanto a polimorfismos de tamanho de fragmentos de restrição (RFLP) do DNAmit, tendo sido caracterizados 53 sítios de restrição. Polimorfismos de sítio e de tamanho de alguns fragmentos específicos foram caracterizados, bem como casos de heteroplasmia envolvendo variações de tamanho. Em T. divaricatus, estas variações correspondem a 50-200 pb, provavelmente localizadas na região controle da molécula; em T. amathites, a variação é provavelmente devida a uma duplicação ou deleção de um segmento de 400 pb. A taxa de mutação envolvendo tamanho de fragmentos mostrou-se menor em T. amathites, quando comparada a T. divaricatus. Índices relativamente baixos de diversidade de nucleotídeos foram detectados em todas as populações analisadas, os menores sendo encontrados nas populações de T. nanuzae. T. divaricatus de Alagoado mostrou-se a população mais polimórfica, seguida da população de Ibiraba. É sugerido que estas duas populações possam estar recuperando a diversidade quanto ao DNAmit após possíveis reduções nos tamanhos populacionais. O maior grau de polimorfismo encontrado em $T$. divaricatus talvez reflita uma expansão populacional recente nesta espécie.

\section{REFERENCES}

Árnason, E. and Rand, D.M. (1992). Heteroplasmy of short tandem repeats in Atlantic cod (Gadus morhua). Genetics 132: 211-220.

Arruda Campos, C.V. (1999). Caracterização de lagartos microteídeos do gênero Calyptommatus (Squamata, Gymnophtalmidae) através da análise de fragmentos de restrição do DNA mitocondrial. Master's thesis, Instituto de Biociências, USP, São Paulo.

Avise, J.C. (1994). Molecular Markers, Natural History and Evolution. Chapman and Hall, New York, London, pp. 511.

Densmore, L.D., Wright, J.W. and Brown, W.M. (1985). Length variation and heteroplasmy are frequent in mitochondrial DNA from parthenogenetic and bisexual lizards (genus Cnemidophorus). Genetics 110: 689-707.

Dowling, T.E., Moritz, C. and Palmer, J.D. (1990). Nucleic acids II: restriction site analyses. In: Molecular Systematics (Hillis, D.M. and Moritz, C., eds.). Sunderland, Sinauer, pp. 250-317.

Hauswirth, W.W., Lim, L.O., Dujon, B. and Turner, G. (1987). Methods for studying the genetics of mitochondria. In: Mitochondria - A Practical Aproach (Darley-Usmar, V.M., Rickwood, D. and Wilson, M.T., eds.). IRL Press, Oxford, pp. 171-224.

Hillis, D.M. and Davis, S.K. (1986). Evolution of ribosomal DNA: Fifty million years of recorded history in the frog genus Rana. Evolution 40: 1275-1288

Kasahara, S., Yonenaga-Yassuda, Y. and Rodrigues, M.T. (1987). Karyotype and evolution of the Tropidurus nanuzae species group (Sauria, Iguanidae). Rev. Bras. Genet. X: 185-197.

Martins, J.M. (1991). Estudo das alozimas de lagartos do gênero Tropidurus do grupo nanuzae (Sauria, Iguanidae). Master's thesis, Instituto de Biociências, USP, São Paulo.

Martins, J.M. (1995). Allozyme variation and expression in lizards of the Tropidurus nanuzae species group (Iguania: Tropiduridae). Copeia 3: 665-675.

Moritz, C. and Brown, W.M. (1986). Tandem duplication of D-loop and ribosomal RNA sequences in lizard mitochondrial DNA. Science 233: $1425-1427$

Moritz, C. and Brown, W.M. (1987). Tandem duplications in animal mitochondrial DNAs: Variation in incidence and gene content among lizards. Proc. Natl. Acad. Sci. USA 84: 7183-7187.

Moritz, C., Dowling, T.E. and Brown, W.M. (1987). Evolution of animal mitochondrial DNA: relevance for population biology and systematics. Annu. Rev. Ecol. Syst. 18: 269-292.

Moritz, C., Case, T.J., Bolger, D.T. and Donnellan, S. (1993). Genetic diversity and the history of Pacific island house geckos (Hemidactylus and Lepidodactylus). Biol. J. Linn. Soc. 48: 113-133.

Nei, M. and Li, W.-H. (1979). Mathematical model for studying genetic variation in terms of restriction endonucleases. Proc. Natl. Acad. Sci. USA 76: 5269-5273.

Nei, M. and Tajima, F. (1981). DNA polymorphism detectable by restriction endonucleases. Genetics 97: 145-163.

Rand, D.M. (1993). Endotherms, ectotherms, and mitochondrial genome-size variation. J. Mol. Evol. 37: 281-295.

Rodrigues, M.T. (1986). Um novo Tropidurus com crista dorsal do Brasil com comentários sobre suas relações, distribuição e origem (Sauria, Iguanidae). Pap. Avulsos Zool. 36: 171-179.

Rodrigues, M.T. (1996). Lizards, snakes, and Amphisbaenians from the Quaternary Sand Dunes of the Middle Rio São Francisco, Bahia, Brazil. J. Herpetol. 30: 513-523.

Skuk, G.O. (1994). Variação geográfica, ecologia e relações filogenéticas das espécies de Tropidurus do grupo nanuzae. Master's thesis, Instituto de Biociências, USP, São Paulo.

Stephan, W. and Langley, C.H. (1992). Evolutionary consequences of DNA mismatch inhibited repair opportunity. Genetics 132: 567-574.

(Received June 17, 1999) 